\title{
Biopsy-defined adult celiac disease in Asian-Canadians
}

\author{
Hugh James Freeman MD
}

\begin{abstract}
HJ Freeman. Biopsy-defined adult celiac disease in AsianCanadians. Can J Gastroenterol 2003;17(7):433-436.

Celiac disease is thought to be a genetically based disorder reported mainly from European countries as well as countries to which Europeans have emigrated, including North America. This report documents a clinical experience of biopsy-defined celiac disease in 14 Asians diagnosed since 1988 in a single Canadian teaching hospital. Eleven were Indo-Canadians, including 10 of Punjabi descent. Other ethnic groups were also represented, including two Japanese and one Chinese patient. Abdominal pain was the most frequent presenting symptom. Anemia, particularly associated with a deficiency of iron was common, along with diarrhea and weight loss. Endoscopic studies documented lymphocytic gastric and colonic mucosal changes in over one-third of the cases while antibodies for tissue transglutaminase were positive in all patients tested. Dermatitis herpetiformis, diabetes mellitus and autoimmune liver disease were also documented. These findings indicate for the first time that adult celiac disease occurs in Asian populations living in North America, particularly in those of Punjabi descent.
\end{abstract}

Key Words: Celiac disease; Environmental factors in celiac disease; Genetics; Gluten-free diet; Small bowel biopsy; Tissue transglutaminase assay

\section{Confirmation par biopsie de la maladie cæliaque de l'adulte chez les Canadiens d'origine asiatique}

\begin{abstract}
On croit que la maladie cæliaque aurait une forte composante génétique et qu'elle affecterait principalement les populations d'Europe et les terres d'accueil d'émigrants d'origine européenne, y compris l'Amérique du Nord. Le présent article relate une expérience clinique menée sur la maladie cæliaque diagnostiquée au moyen de la biopsie chez 14 sujets asiatiques depuis 1988 dans un seul centre hospitalier universitaire canadien. Onze de ces patients étaient des Indo-Canadiens, dont 10 du Pendjab. D'autres groupes ethniques étaient également représentés parmi ces patients qui comptaient deux Japonais et un Chinois. Dans la plupart des cas, c'est la douleur abdominale qui avait amené les patients à consulter. L'anémie, surtout associée à une carence en fer, était également fréquente, ainsi que la diarrhée et la perte de poids. L'endoscopie a confirmé la présence d'anomalies lymphocytaires de la muqueuse de l'estomac et du côlon chez plus du tiers des sujets, tandis que tous présentaient des résultats positifs aux test de dépistage des anticorps dirigés contre la transglutaminase tissulaire. On a aussi noté des cas de dermatite herpétiforme, de diabète sucré et de maladie hépatique auto-immune. Ces observations permettent pour la première fois de conclure que la maladie cæliaque de l'adulte affecte les populations nord-américaines d'origine asiatique, et plus particulièrement les Punjabi.
\end{abstract}

$\mathrm{C}$ eliac disease is a genetically based disorder diagnosed mainly in Europe and in those countries to which Europeans have emigrated, including North America. Interestingly, the disorder is also relatively common in northern India, where there is a long history of wheat cultivation before $1000 \mathrm{BC}(1)$ and a high frequency of specific human leukocyte antigen (HLA) marker molecules that have been associated with celiac disease (2-4). Moreover, some early studies documented celiac disease in wheat-eating areas of Bengal and Punjab, compared with the predominantly rice-eating areas of southern India $(5,6)$, as well as in Indian and Pakistani immigrant children in England (7,8). Indeed, in the South Asian population of Leicestershire, particularly in Punjabis, the incidence of celiac disease was reported to be even higher than in Europeans (9). Others have also recorded celiac disease in Cantonese children (10) and, more recently, Japanese children (11). In addition, there are rare reports of celiac disease in natives from North and South America, thought to be descendents from Asians (12,13).

Previous studies from Vancouver have detailed clinical, pathological and serological features of different forms of inflammatory bowel diseases, including both ulcerative colitis and Crohn's disease, in both Chinese and Indo-Canadians (1418). To date, however, there are no published studies on adult celiac disease in either Asian immigrants or individuals of Asian descent in North America. This report documents a clinical experience of biopsy-defined adult celiac disease in Asians diagnosed during the past two decades at a single teaching hospital in Vancouver, British Columbia. These findings indicate that adult celiac disease can occur in different AsianCanadian populations, particularly in Indo-Canadians that have descended from the Punjab region of Northern India.

\section{PATIENTS AND METHODS}

During a 21-year period from January 1982 to December 2002 inclusive, 214 patients with adult celiac disease were seen by the investigator; of these, 14 were of Asian descent and all of these were diagnosed at the University of British Columbia Hospital, Vancouver, British Columbia. Complete office and hospital records were reviewed for details of clinical presentation and laboratory studies (hemogram, liver chemistry tests, immunoglobulins, carotene, iron and iron binding capacity, ferritin, folic acid, vitamin $B_{12}$, calcium, magnesium, glucose, proteins, including albumin, and thyroid function studies). Fecal specimens for bacterial

Department of Medicine (Gastroenterology), University of British Columbia, Vancouver, British Columbia, Canada

Correspondence and reprints: Dr Hugh Freeman, Gastrointestinal Diseases, University of British Columba Hospital, 2211 Wesbrook Mall,

Vancouver, British Columbia V6T IW5. Telephone 604-822-7216, fax 604-822-7236 
and parasitic studies were negative. After small intestinal biopsies were done, all patients were seen by a clinical dietitian to provide specific instructions on the gluten-free diet. Patients were periodically evaluated, as required, to address concerns regarding diet treatment. Compliance and response to a prescribed gluten-free diet were repeatedly assessed. For some patients, another family member or interpreter was also instructed on the gluten-free diet. None of the Asian patients reported here had a familial history of celiac disease.

The diagnosis of celiac disease for each patient was based on small intestinal biopsies, done before and after the institution of a gluten-free diet (19). Severely abnormal 'flat' small intestinal biopsies (so-called 'crypt hyperplastic villous atrophy') were reported before the institution of a gluten-free diet (19). Dietary treatment was started within two weeks. In all patients, a second small intestinal biopsy was done at least three months after the initiation of the gluten-free diet to demonstrate normalization of the abnormal structural changes (19). In some patients, additional small intestinal biopsies were required to ensure persisting histological improvement. Endoscopic studies of the stomach and colon were also done and biopsies were obtained from both the gastric and the colonic mucosa to exclude other previously reported microscopic inflammatory diseases seen in celiac disease (ie, lymphocytic and/or collagenous gastritis and/or lymphocytic and/or collagenous colitis) (20-23). In addition, results of special stains for Helicobacter pylori, done in each patient, were recorded. After serum assays for tissue transglutaminase antibodies were developed for research purposes in the University of British Columbia Hospital laboratory (24), separate clinical assays were developed in the hospital. For the patients in the present study, all four that were tested had positive tissue transglutaminase antibody results using this clinical assay, but only after initial biopsy results were known, and before the institution of a gluten-free diet.

\section{RESULTS}

In the present series, there were 14 patients of Asian descent with biopsy-defined celiac disease. Of these, two were Japanese-Canadians, one was Chinese-Canadian and 11 were Indo-Canadians. Most (eight or $57.1 \%$ ) had emigrated from Asia, but five $(35.7 \%)$ were born in Canada, including one Japanese-Canadian female (Richmond, British Columbia in 1931) and four Indo-Canadians (two males, two females), all with parents born in Northern India (Punjab region). Finally, one Indo-Canadian male, born in Malawi, emigrated to Canada in 1975; both of his parents were also born in Northern India (Punjab). Table 1 shows epidemiological data for the 14 patients, diagnosed from 1988 to 2002 . There were seven male patients and seven females, with 13 diagnosed in the past decade. Of the 11 Indo-Canadians, 10 were either born or direct descendents from parents born in the Punjab region; only one Indo-Canadian female, recently diagnosed, was born east of Bombay. For this Indo-Canadian group, all had resided in Canada for prolonged periods of time, ranging from 17 to 32 years before a diagnosis of celiac disease was established (mean of 24 years). Interestingly, the oldest patient in this study, a Chinese-Canadian woman, was born in Northern China. She came to Vancouver in 1973. Historically, her diet was primarily wheat-based, rather than rice-based, even in Northern China.

Table 2 details clinical features of the 14 patients of Asian descent with biopsy-defined celiac disease. There were seven females and seven males. For this group of Asians with celiac
TABLE 1 Epidemiological data on Asians with biopsy-defined celiac disease

\begin{tabular}{llclcc}
\hline Age/Sex & $\begin{array}{l}\text { Ethnic } \\
\text { group }\end{array}$ & $\begin{array}{c}\text { Year } \\
\text { of birth }\end{array}$ & $\begin{array}{c}\text { Place } \\
\text { of birth }\end{array}$ & $\begin{array}{c}\text { Year of } \\
\text { diagnosis }\end{array}$ & $\begin{array}{c}\text { Years }^{\dagger} \text { in } \\
\text { Canada }\end{array}$ \\
\hline 18/M & Japanese & 1970 & Japan & 1988 & 10 \\
69/F & Chinese & 1924 & $\begin{array}{c}\text { Northern } \\
\text { China }\end{array}$ & 1993 & 20 \\
& & & Canada & 1993 & 61 \\
61/F & Japanese & 1931 & Malawi* & 1996 & 21 \\
36/M & Indian & 1959 & Munjab, India & 2002 & 22 \\
44/M & Indian & 1957 & Pun & 17 \\
17/F & Indian & 1978 & Canada* & 1995 & 19 \\
19/M & Indian & 1978 & Canada* & 1998 & 19 \\
19/F & Indian & 1979 & Canada* & 1998 & 32 \\
41/F & Indian & 1958 & Punjab, India & 2000 & 24 \\
44/M & Indian & 1952 & Punjab, India & 1996 & 20 \\
51/M & Indian & 1945 & Punjab, India & 1997 & 31 \\
31/M & Indian & 1966 & Canada* & 1997 & 32 \\
53/F & Indian & 1950 & Punjab, India & 2002 & 27 \\
64/F & Indian & 1938 & Eastern India & 2002 & \\
\hline
\end{tabular}

${ }^{*}$ Parents born in Punjab, India; ${ }^{\dagger}$ Before diagnosis

disease, three of 14 ( or 21.4\%) were over the age of 60 years at the time of their initial diagnosis and all of these patients were women. This is consistent with the increasing recognition of celiac disease in the elderly reported elsewhere from this hospital (25). Before 1993, only one patient was diagnosed with celiac disease. During the next decade, diagnoses of celiac disease were made sporadically with no more than three new patients detected in any specific calendar year. Although not used as a clinical screening tool in these patients, it is of interest that sera obtained for tissue transglutaminase (from the year 2000 when the assay was first established in this hospital clinical laboratory) in all four patients with a biopsy-defined diagnosis were positive. To date, no patient with Immunoglobulin A deficiency has been detected in this Asian group.

Clinical symptoms were also recorded. Abdominal pain (71.4\%), diarrhea (35.7\%) and weight loss $(57.1 \%)$ were common, usually for less than two years. Anemia (42.8\%) and deficiencies of various nutrients, particularly iron, were common. Endoscopic studies are also detailed in Table 2. To date, no esophageal inflammatory or neoplastic disease were detected. Lymphocytic gastritis, lymphocytic colitis, or both, were present in five patients $(35.7 \%)$. Collagenous inflammatory diseases were not detected in the stomach, small intestine or colon. Only one patient had gastritis associated with $\mathrm{H}$ pylori. To date, no neoplastic disorder has developed in any of these 14 patients.

\section{DISCUSSION}

The present report documents the detection of biopsy-defined adult celiac disease in Asian immigrants and those of Asian descent born in Canada, and represents new information on celiac disease in North America. Most of the patients in the present study were Indo-Canadian, either born in the Punjab region of Northern India or of Punjabi descent. This finding in adults is consistent with previously recorded evidence for celiac disease, notably in children, in the Punjab region as well as in children of Punjabi descent in the United Kingdom (6-9). 
TABLE 2

Clinical features in Asians with celiac disease

\begin{tabular}{|c|c|c|c|c|}
\hline Age/Sex & Ethnic group & $\begin{array}{c}\text { Year of } \\
\text { diagnosis }\end{array}$ & Symptoms & Complications \\
\hline$\overline{18 / M}$ & Japanese & 1988 & Abdominal pain, $4 \mathrm{~kg}$ weight loss & \\
\hline $69 / F$ & Chinese & 1993 & $\begin{array}{l}\text { Abdominal pain, } \\
10 \mathrm{~kg} \text { weght loss }\end{array}$ & $\begin{array}{l}\text { Iron deficiency anemia, folate and B12 deficiency } \\
\text { hypomagnesemia }\end{array}$ \\
\hline $61 / F$ & Japanese & 1993 & Diarrhea & Helicobacter pylori-associated gastritis \\
\hline $36 / \mathrm{M}$ & Indian & 1996 & $\begin{array}{l}\text { Abdominal pain, diarrhea, } \\
10 \mathrm{~kg} \text { weight loss }\end{array}$ & $\begin{array}{l}\text { Iron deficiency anemia, Low serum albumin } \\
\text { elevated AST, lymphocytic gastritis }\end{array}$ \\
\hline $44 / \mathrm{M}$ & Indian & 2002 & Abdominal pain & Tissue transglutaminase antibody-positive \\
\hline $17 / F$ & Indian & 1996 & $\begin{array}{l}\text { Abdominal pain, diarrhea } \\
8 \mathrm{~kg} \text { weight loss }\end{array}$ & $\begin{array}{c}\text { Gallstones, lymphocytic colitis, dermatitis } \\
\text { herpetiformis, lymphocytic gastritis, iron } \\
\text { deficiency anemia, low serum albumin }\end{array}$ \\
\hline 19/M & Indian & 1998 & Abdominal pain & \\
\hline $19 / F$ & Indian & 1998 & Abdominal pain & Lymphocytic colitis \\
\hline $41 / \mathrm{F}$ & Indian & 2000 & Abdominal pain & $\begin{array}{l}\text { Lymphocytic gastritis, tissue transglutaminase } \\
\text { antibody-positive }\end{array}$ \\
\hline $44 / \mathrm{M}$ & Indian & 1997 & Diarrhea, $20 \mathrm{~kg}$ weight loss & $\begin{array}{l}\text { Gallstones, CAH with fibrosis (autoimmune), } \\
\text { Iron deficiency anemia }\end{array}$ \\
\hline $51 / \mathrm{M}$ & Indian & 1996 & $6 \mathrm{~kg}$ weight loss & Iron deficiency anemia, lymphocytic gastritis \\
\hline $31 / \mathrm{M}$ & Indian & 1997 & $\begin{array}{l}\text { Abdominal pain, } \\
4 \mathrm{~kg} \text { weight loss }\end{array}$ & Epilepsy, iron deficiency anemia \\
\hline $53 / \mathrm{F}$ & Indian & 2002 & Abdominal pain, diarrhea & Tissue transglutaminase antibody-positive \\
\hline $64 / F$ & Indian & 2002 & $8 \mathrm{~kg}$ weight loss & Tissue transglutaminase antibody-positive, diabetes \\
\hline
\end{tabular}

AST Aspartate aminotransferase; CAH Chronic active hepatitis

In addition, the present report documents the histological definition of celiac disease in other Asian ethnic groups residing in North America, including Chinese and Japanese immigrants and those of Asian descent born in Canada. Similar observations were previously recorded in natives among the Coast Salish (12) who were thought to be descended from populations that historically migrated from Asia to North America over the Alaskan land bridge. Previous studies, using HLA markers (2-4), have suggested that celiac disease in these ethnic groups is largely, but not solely, genetically based, requiring an environmental factor (ie, wheat) for the expression of the disease. Wheat cultivation methods were recorded in the Punjabi region of India before 1000 BC. This was hypothesized elsewhere to be important in the appearance of celiac disease in this particular geographic area of Asia (1). In addition, as suggested by the sole Chinese patient in this report, wheat cultivation may be as important a staple as rice in Northern China. Finally, the relatively late introduction of wheat cultivation methods in the past century to North American native groups, such as the Coast Salish, may be important in the limited, but relatively recent recognition of celiac disease in these groups (12).

The clinical features of adult celiac disease were also detailed. Abdominal pain, a less common symptom in most celiac disease series (26), was the most frequently defined symptom leading to investigation, along with weight loss and diarrhea. In part, this may have reflected the adult age of the patients studied, because abdominal pain appears also to be a less commonly reported symptom in Indian children with celiac disease (27). Anemia was also commonly detected, particularly iron deficiency anemia, similar to the experience with adult celiac disease reported from India (28). Serological studies were not systematically done in our patients before the more recent development of a clinical assay in our hospital.
However, since becoming available, the serum assay for tissue transglutaminase was positive in all patients with biopsydefined celiac disease. In a previous study, tissue transglutaminase autoantibodies had been reported in an Indian population with diabetes (29). Further studies are needed to determine the value of this assay as a screening tool for celiac disease in selected immigrant populations. Finally, this investigation documented concomitant lymphocytic inflammatory changes in gastric and colonic mucosa in over one-third of the patients. This was similar to the previously recorded prevalence figures in celiac disease (30) as well as the presence of other 'autoimmune' features of celiac disease, including dermatitis herpetiformis, diabetes and chronic liver disease.

\section{CONCLUSIONS}

The present report documents an experience with celiac disease in Asian immigrants as well as in those of Asian descent born in Canada, from differing ethnic backgrounds. These findings from a single teaching hospital suggest that this occurs far more frequently than is currently appreciated, particularly in those of Punjabi descent.

\section{REFERENCES}

1. Simoons FJ. Coeliac disease as a geographic problem. In: Walcher DN, Kretchmer N, eds. Food, Nutrition and Evolution. New York: Masson, 1981:179-99.

2. Agrawal S, Gupta A, Yachha SK, Muller-Myhsok B, Mehrotra P, Agarwal SS. Association of human leukocyte-DR and DQ antigens in celiac disease: A family study. J Gastroenterol Hepatol 2000;15:771-4.

3. Mehra NK, Kaur G, Kanga U, Tandon N. Immunogenetics of autoimmune diseases in Asian Indians. Ann NY Acad Sci 2002;958:333-6.

4. Kaur G, Sarkar N, Bhatnagar S, et al. Pediatric celiac disease in India is associated with multiple DR3-DQ2 haplotypes. Hum Immunol 2002;63:677-82. 
5. Misra RC, Kasthuri D, Chuttani HK. Adult celiac disease in tropics. Br Med J 1966;2:1230-2.

6. Walia BNS, Sidhu JK, Tandon BN, Ghai OP, Bhargava S. Coeliac disease in North Indian children. Br Med J 1966;2:1233-4.

7. Brueton MJ, Abidin Z, Anderson CM. Coeliac disease in Asian children in the United Kingdom. In: McConnell RB, ed. The Genetics of Coeliac Disease. Lancaster: MTP Press, 1981:103-6.

8. Nelson R, McNeish AS, Anderson CM. Coeliac disease in children of Asian immigrants. Lancet 1973;1:348-50.

9. Sher KS, Fraser RC, Wicks AC, Mayberry JF. High risk of coeliac disease in Punjabis. Epidemiological study in the south Asian and European populations of Leicestershire. Digestion 1993;54:178-82.

10. McNeish AS, Rolles CJ, Nelson R, Kyaw-Myint TO, MacKintosh P, Williams AF. Factors affecting the differing racial incidence of coeliac disease. In: Hekkens WTJM, Pena AS, eds. Coeliac Disease. Leiden: Stenfert Kroese, 1974;330-7.

11. Shaoul R, Marcon MA, Okada Y, Cutz E, Forstner G. Gastric metaplasia: A frequently overlooked feature of duodenal biopsy specimens in untreated celiac disease. J Pediatr Gastroenterol Nutr 2000;30:397-403.

12. Freeman HJ. Celiac disease associated with primary biliary cirrhosis in a Coast Salish native. Can J Gastroenterol 1994;8:105-7.

13. Araya M, Mondragon A, Perez-Bravo F, et al. Celiac disease in a Chilean population carrying Amerindian traits. J Pediatr Gastroenterol Nutr 2000;31:381-6.

14. Chaun H, Freeman HJ. Crohn's disease in Chinese people in Vancouver, British Columbia. Can J Gastroenterol 1993;7:28-32.

15. Chaun H, Freeman HJ. Ulcerative colitis in the Chinese population of Vancouver, British Columbia. 1994;8:303-7.

16. Freeman HJ. Inflammatory bowel disease with cytoplasmic-staining antineutrophil cytoplasmic antibody and extensive colitis. Can J Gastroenterol 1998;12:279-82.

17. Freeman HJ. Inflammatory bowel diseases in Indo-Canadians with and without antineutrophil cytoplasmic autoantibodies. Can J Gastroenterol 2000;14:21-6.
18. Freeman HJ, Hershfield NB. Anticipation in an Indo-Canadian family with Crohn's disease. Can J Gastroenterol 2001;15:695-8.

19. Freeman HJ. Small intestinal mucosal biopsy for investigation of diarrhea and malabsorption in adults. Gastrointestinal Endo Clin North Am 2000;10:739-53.

20. Freeman HJ, Piercey JRA, Raine RJ. Collagenous gastritis. Can J Gastroenterol 1989;3:171-4.

21. Wolber R, Owen D, DelBuono L, Appelman H, Freeman HJ. Lymphocytic gastritis in patients with celiac sprue or sprue-like intestinal disease. Gastroenterology 1990;98:310-5.

22. Wolber R, Owen D, Freeman HJ. Colonic lymphocytosis in patients with celiac sprue. Human Pathol 1990;21:1092-6.

23. Freeman HJ. Collagenous inflammatory mucosal diseases of the gastrointestinal tract. Can J Gastroenterol 1990;4:196-200.

24. Gillett HR, Freeman HJ. Comparison of IgA endomysium antibody and IgA tissue transglutaminase antibody in celiac disease. Can J Gastroenterol 2000;14:668-71.

25. Freeman HJ. Clinical spectrum of biopsy-defined celiac disease in the elderly. Can J Gastroenterol 1995;9:42-6.

26. Cooke WT, Holmes GKT. Coeliac Disease. Edinburgh: Churchill Livingstone, 1984:83.

27. Mohindra S, Yachha SK, Srivastava A, et al. Coeliac disease in Indian children: Assessment of clinical, nutritional and pathologic characteristics. J Health Popul Nutr 2001;19:204-8.

28. Varma S, Malhotra P, Kochhar R, Varma N, Kumari S, Jain S. Celiac disease presenting as iron-deficiency in northern India. Indian J Gastroenterol 2001;20:234-6.

29. Kanungo A, Shtauvere-Brameus A, Samal KC, Sanjeevi CB. Autoantibodies to tissue transglutaminase in patients from eastern India with malnutrition-modulated diabetes mellitus, insulindependent diabetes mellitus, and non-insulin-dependent diabetes mellitus. Ann NY Acad Sci 2002;958:232-4.

30. Gillett HR, Freeman HJ. Prevalence of celiac disease in collagenous and lymphocytic colitis. Can J Gastroenterol 2000;14:919-21. 


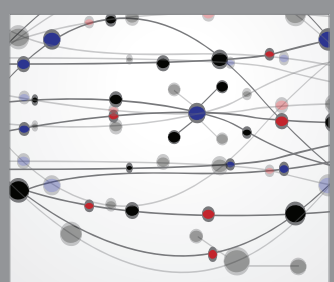

The Scientific World Journal
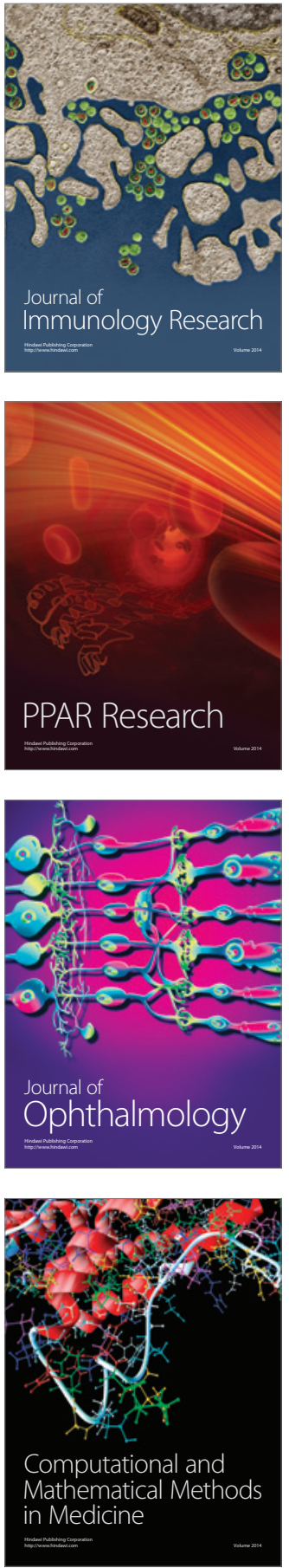

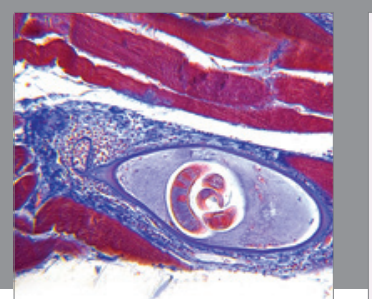

Gastroenterology Research and Practice

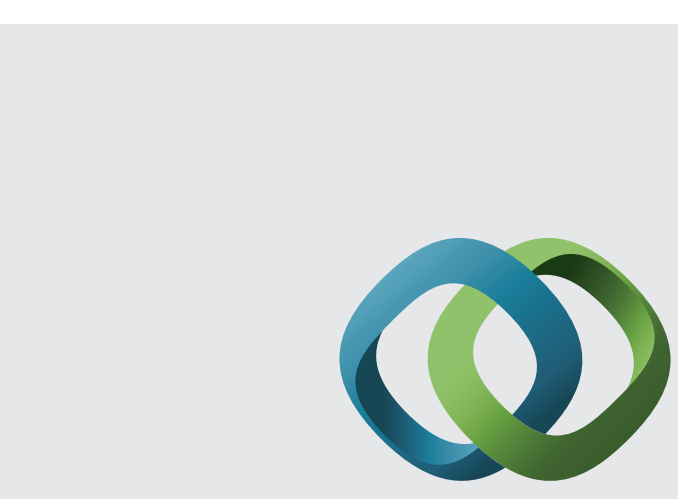

\section{Hindawi}

Submit your manuscripts at

http://www.hindawi.com
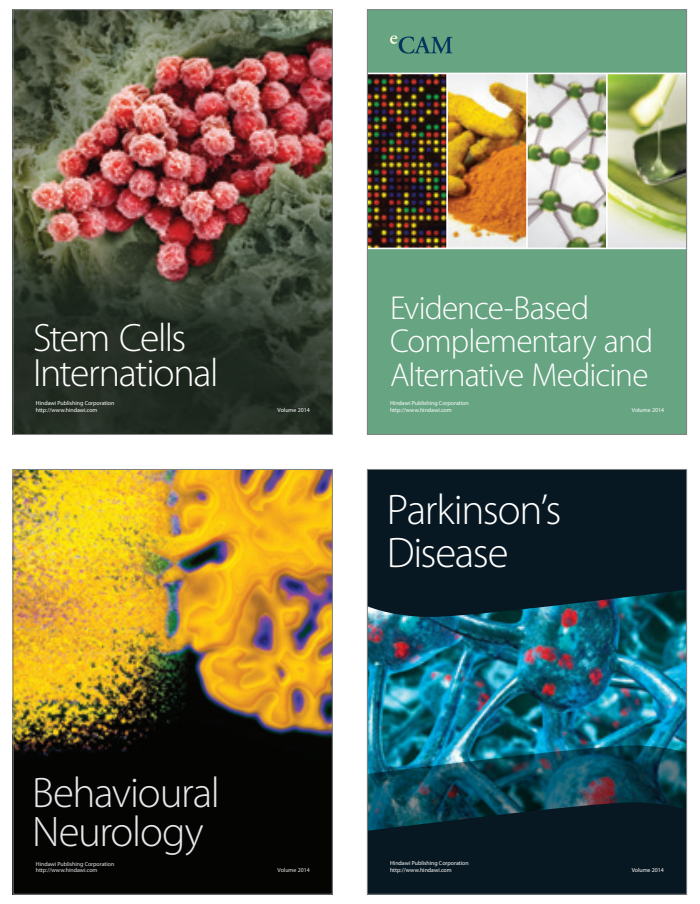
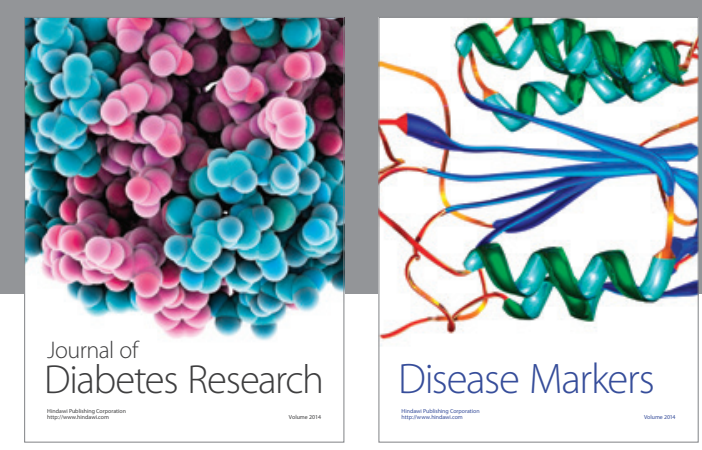

Disease Markers
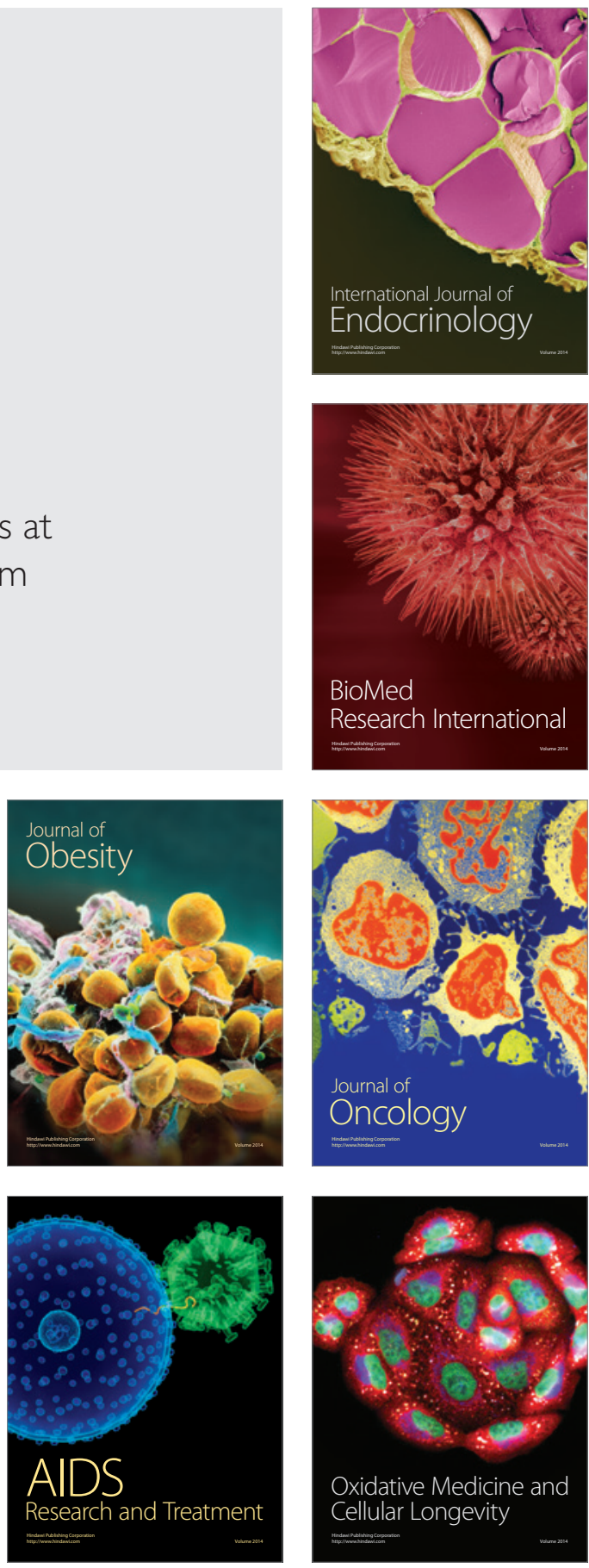